\title{
СОЦИАЛЬНАЯ АДАПТАЦИЯ ДЕТЕЙ-МИГРАНТОВ В ОБЩЕОБРАЗОВАТЕЛЬНОЙ ШКОЛЕ
}

\section{SOCIAL ADAPTATION OF MIGRANT CHILDREN IN SECONDARY SCHOOL}

\author{
МУНКОЕВА Н.А. \\ MUNKOEVA N.A. \\ Педагогический институт Иркутского \\ Pedagogy Institute, Irkutsk State University \\ государственного университета
}

hilhanova1995@mail.ru

doi: $10.18411 /$ pivsn-03-2019-24

idsp: sciencepub-pivsn-03-2019-24

\section{АННОТАЦИЯ}

В статье рассмотрена проблема адаптации детей-мигрантов. Представлены проблемы детей-мигрантов с подробным описанием. Выявляется необходимость в комплексном психолого-педагогическом сопровождении, включающих все субъекты современного образования.

КЛЮЧЕВЫЕ СЛОВА. Дети-мигранты, миграция, социальная адаптация, стресс, интеграция, психологические проблемы, психолого-педагогические проблемы.

\section{ABSTRACT}

The article deals with the problem of adaptation of migrant children. The problems of migrant children with a detailed description are presented. The necessity of complex psychological and pedagogical support including all subjects of modern education is revealed.

KEY WORDS. Migrant children, migration, social adaptation, stress, integration, psychological problem, psychological and pedagogical problems.

\section{ВВЕДЕНИЕ}

Миграция как социокультурный феномен не является открытием 90-х гг. XX века, так как в истории России и СССР, и ранее происходила депортация народов, института прописки, например: призывов на работу на великие стройки. По мимо вынужденной миграции так же всегда присутствовала и добровольная миграция, которая имеет в вид социальной мобильности людей (из деревень в город, из соседних областей на новые территории и др.). Особенности феномена миграции, ставшей ведущей тенденцией в социальной жизни нашего государства с конца 80-х гг. XX века, определяется ее стрессовым характером, при этом важными характеристиками самого процесса миграции выступают: обостренные межнациональные, социально-экономические, политические отношения в ряде регионов России и стран СНГ.

Миграция населения - это процесс переселения людей, пересекающих границы тех или иных территорий со сменой места жительства. Последние года миграция характеризуются активизацией процесса [6, с. 28].

В основном, это трудовая миграция: в связи с безработицей и низким уровнем жизни в родной стране, многим семьям с детьми приходится мигрировать в Россию. В настоящее время в школах, по данным статистики, дети мигранты составляют около 30 процентов от общего числа учеников.

Соответственно, возникают проблемы социально-психологической адаптации детей-мигрантов в школах, приехавших с родителями в Россию. Основная проблема, это адаптация детей - мигрантов - это интеграция в общество в процессе обучения. 
Во-первых, дети мигранты находятся в трудных условиях: и они отличаются от среды своего нового местожительства по своей культуре. Такие дети не имеют социальной защиты, и они часто испытывают трудности в общении с одноклассниками.

Во-вторых, одна из особенностей этих детей - двуязычие (билингвизм), связи с которым у них отмечаются учебные трудности в усвоении учебного материала, к тому же наблюдается плохое знание русского языка и слабая дошкольная подготовка. Детимигранты не всегда понимают объяснения учителя, не умеют выразить свою мысль, свою точку зрения и не могут дать правильный ответ на вопрос учителя.

В результате совместного действия данных факторов многие дети-мигранты уже в свои семь-восемь лет начинают воспринимать социум, в котором они вынуждены находиться, как отвергающий, унижающий и дискриминирующий их личность, что в дальнейшем приводит к психологическим травмам.

В социальном плане - адаптация детей мигрантов предполагает приспособление их к новым социальным условиям, общественным явлениям, то есть интеграции в общество, в котором они находятся. А в психологическом плане - установление контакта с ближайшим окружением, нахождение своего места в нем, выработка навыков, действовать исходя из ценностей и норм, свойственных для той культуры, в которой они оказались [7, с. 17]. Миграция детей осложнена тем, что в школах, как правило, отсутствует психолого-педагогическое сопровождение таких детей. Дети в подобных ситуациях в школе испытывают тяжелые внутриличностные переживания, связанные с их приспособлением к совершенно новым условиям и обстоятельствам жизни, о которых ранее они не имели ни малейшего представления [1, с. 88].

К психолого-педагогическим проблемам адаптации к новой образовательной среде следует также отнести сложности отношений детей-мигрантов с учителями: ксенофобия среди учителей, если говорить об обратной связи «учитель - ученик» [3, с. 45], [4, с. 15]. Сам по себе процесс адаптации обозначает стрессовую ситуацию, с которой необходимо справиться личности.

Стрессогенное воздействие новой культуры на человека определяется «культурным шоком». Это конфликт двух культур на уровне индивидуального сознания [7, с. 22]. Встреча мигранта с новой культурой приводит к культурному шоку, проявления которого имеют многочисленность.

Среди них основное место занимают следующие чувства: потеря или лишения практически всех составляющих прежней жизни - родины, статуса, друзей, профессии, имущества; тревоги, связанные с различными эмоциями (удивление, возмущение, отвращение, негодование), возникающими в результате осознания культурных особенностей принимающей страны. Отмечается, что нормы культуры часто радикально отличаются и даже не имеют приближенности. В результате наблюдается путаница в ценностях, сложности в самоидентификации, происходит сбой в ролевой структуре и соответственно социальной $[4$, с. 15$]$.

Яркие проявления культурного шока у детей-мигрантов в школе - хроническое переутомление и психосоматические заболевания, которые возникают в результате активного нервного напряжения, они необходимы для процесса - психологической адаптации.

\section{ЦЕЛЬ ИССЛЕДОВАНИЯ}

Актуальной задачей на сегодняшний день является создание условий в школе, в которых дети-мигранты могли бы благоустроиться и получить образование. Перед социальными педагогами и педагогами - психологами, а так же классными руководителями ставятся цели, которыми являются изучение и обоснование программ психологической адаптации в школе.

\section{РЕЗУЛЬТАТЫ И ИХ ОБСУЖДЕНИЕ}

Так психологические проблемы и психические расстройства вынужденных мигрантов, носят комплексный характер и затрагивают эмоциональную, поведенческую, 
коммуникативную и мотивационно-потребностную сферу личности. Исходя из всего выше сказанного, психолого-педагогическое сопровождение должно иметь комплексный и сочетать социальные, психологические и педагогические средства, методы и разнообразные формы.

Определяется так же, что феномен социально-психологическая адаптация имеет двусторонний процесс, который сопровождается тяжелыми переживаниями не только со стороны мигранта, но и окружающего его социума [2, с. 15]. Меняется не только личность мигранта, но и его новый статус в обществе имеющий для него определенный характер.

При правильном психолого-педагогическом сопровождении должна выработаться новая совместная система поведения, взаимодействия, устраивающая обе стороны. Проблематика адаптации и интеграции детей-мигрантов в школе актуальна и решение данной проблемы состоит в целенаправленном обучении младших школьников взаимодействию и сотрудничеству непосредственно в классных коллективах. Обучать детей взаимодействию и сотрудничеству необходимо сразу же при поступлении в первый класс: это лучший способ избежать формирования и закрепления отрицательных стереотипов, в том числе и этнических. В центре внимания должно находиться, доброжелательное отношение к другому, готовность к обсуждению проблемных ситуаций, и умению находить конструктивные решения в конфликтах [8, с. 15].

\section{ЗАКЛЮЧЕНИЯ}

Сопровождение детей-мигрантов должно иметь комплексный характер, охватывать не только детей мигрантов, но и остальных участников образовательного пространства, педагогов, психологов, всех обучающихся школы и их родителей. Задача учителей состоит не только в обучении, развитии и воспитании подрастающего поколения, а еще и в том, чтобы всем детям в школе было комфортно.

$$
* * *
$$

1. Абозина, Г. А. Классный час для старшеклассников «Толерантность» / Г. А. Абозина // Классный руководитель. - 2006. - № 4. - С. 88-92.

2. Альтман, И. Международный конкурс «Память о Холокосте - путь к толерантности» / И. Альтман // Народное образование. - 2005. - № 4. - С. 131.

3. Андрияхина, Н. В. Семинар-тренинг «Толерантность учителя» / Н. В. Андрияхина // Классный руководитель. - 2010. - № 4. - С. 20-34.

4. Горленко Н.М., Запятая О.В., Лебединцев В.Б., Ушева Т.Ф. Структура универсальных учебных действий и условия их формирования // Народное образование. - 2012. - № 4. - С. 153-160.

5. Громова, Е. Развитие этнической толерантности в школе / Е. Громова // Воспитание школьников. 2011. - № 1. - С. 13-18.

6. Еременко, О. И. Воспитание толерантного сознания в процессе обучения русскому языку / О. И. Еременко, Т. В. Яковлева // Начальная школа. - 2011. - № 3. - С. 28.

7. Кленова, Н. В. Как воспитать толерантность / Н. В. Кленова // Дополнительное образование. - 2010. № 3. - C. 17-22.

8. УшеваТ.Ф. Технологические особенности формирования рефлексивной компетентности учащихся // Школьные технологии. - 2017. - № 6. - С. 34-40. 